\title{
Rebellion and Resistance in French Indochina in the First World War
}

Jonathan Krause

\begin{abstract}
The First World War was not merely a clash of empires, it was also a clash within empires. This fact remains largely ignored despite the dozens of anticolonial uprisings around the world which erupted during, and as a result of, the war. In 1916 alone there were uprisings across French North, West and Equatorial Africa, in Portuguese Angola and Mozambique, the Middle East, Central Asia, Southeast Asia and Ireland. Most of these uprisings were responding both to European efforts to extract resources (especially manpower) from the colonies to support the war effort, whilst also taking advantage of the reduced presence of European troops in Asia and Africa as men were recalled from the colonies to take part in the war in Europe. This article examines anticolonial rebellions in French Indochina, especially the attack on Saigon Central Prison in 1916, as a case study in the wider global history of anticolonial rebellion during the Frist World War. Examination of this rebellion shows how the First World War not only generated the opportunities and challenges which led to a surge of anticolonial uprisings around the world, but also changed the political, social and religious character of anticolonial struggle in Indochina. This article offers a reappraisal of the global and imperial consequences of the First World War, and argues that anticolonialism should be more central in our discussion and memory of the conflict.
\end{abstract}

KEYWORDS: First World War, rebellion, Indochina, anticolonial, Saigon, empire

On the night of 2/3 February 1916 Nguyen Anh Hue, sometimes referred to as 'Professor Hue' and the 'soothsayer of Saigon', arrived at the house of a man called Truong Van No, in the village of Cua Lap $^{1}$. He brought with him plans for an insurrection stretching from Cambodia to Cochinchina ${ }^{2}$ (southern Indochina), to be launched in less than two weeks. Within days hundreds of rebels, men and women, found themselves making active preparations for their own small, local part in a grand uprising against French rule in Southeast Asia. Their preparations had not gone unnoticed. French authorities had received warning from an anonymous source that the conspirators would gather at Truong Van No's house on the night of 13/14 February. French gendarmes arrived at Cua Lap at 23.00 on 13 February to find the village abandoned, save for a single house lit up. Inside the French found over 100 men and women who had taken oaths before a revolutionary flag ${ }^{3}$. They scattered upon the French arrival. 13 were captured and arrested (ten men and three women). Four more were caught trying to swim across one of the countless rivers of the Mekong Delta and escape. Those arrested had their houses searched. Inside the French found lances, machetes, sabres, and bamboo spears: preparations for an imminent rebellion.

The French raid on Cua Lap did not deter the vast majority of conspirators who had managed to escape. They went on to launch an ill-fated attack on Ba Ria and Cap Saint-Jacques the very next night: 14/15 February 1916. These attacks were not isolated, but were part of a larger rebellion that raged across Cochinchina and into Cambodia. While the rebellion ultimately failed, it was 
nevertheless an important moment for anticolonialism in the region, and part of a global trend of anticolonial rebellion during the First World War. This article primarily focuses on the signature effort of the rebellion in French Indochina in 1916: the attack on Saigon Central Prison. This rebellion was sparked, at least in part, by military recruitment, showing how the First World War

influenced pre-existing patterns of anticolonial rebellion which eventually led to the development of nationalist and communist movements in the following decades. Analysis of the attack on Saigon Central Prison helps flesh out an under-explored facet of the global impact of the First World War.

The rebellions in Indochina in 1916 and 1917 were not isolated incidents. Nearly every major French colony experienced some form of organised anticolonial resistance during, and as a direct result of, the First World War ${ }^{4}$. Algeria, Morocco, Tunisia, Senegal, Niger, Mali, Chad, Burkina Faso,

Madagascar, New Caledonia, and Indochina all experienced rebellion of some notable scope ${ }^{5}$. Similar patterns of unrest also developed in the British, Russian, Italian and Ottoman empires during the First World War, suggesting a global moment for anticolonialism. These rebellions took place for many different reasons, in a wide range of historical, cultural, political and economic contexts. For all their contextual diversity, however, the anticolonial rebellions that erupted from 1914 through to the 1920s could not help but be influenced by the realities presented by the First World War. Principal among these were the reduction of colonial occupation forces across Africa and Asia and the recruitment of Afro-Asians for military and industrial service in Europe, often through coercive means. The direct influence of aspects of the First World War in sparking anticolonial rebellions across large swathes of Africa and Asia demand that we discuss these rebellions as part of both the global experience and legacy of the First World War.

In most mainstream, general histories of the First World War the anticolonial rebellions in Africa and Asia have largely been ignored, both individually and as part of a collective experience ${ }^{6}$. Even in Anglophone books more closely focused on Africa in the First World War major anticolonial wars like the Volta-Bani and Senussi wars are avoided ${ }^{7}$. Slowly, however, new research is bringing the anticolonial aspects of the First World War into greater prominence. In 2014 Joshua Sanborn wrote in his book Imperial Apocalypse: the Great War \& the Destruction of the Russian Empire that

Decolonization was a crucial aspect of the war from its beginning right through to its end, but it continues to be largely ignored by the mainstream scholarship.... Indeed, scholars have generally ignored the dynamic of decolonization even for the later stages of the conflict... when the process became virtually impossible to miss ${ }^{8}$.

The work Sanborn and others have done in recent years on the anticolonial rebellions in Central Asia has helped redefine, once again, the limits of what might be considered part of the First World War, in its grandest sense. In a similar vein Erez Manela's The Wilsonian Moment: Self-Determination and

the International Origins of Anticolonial Nationalism argued that the First World War constitutes 'a single historical moment' for anticolonialism; a global affair born of a global conflict ${ }^{9}$. Other recent works confirm this conception of anticolonialism in the First World War as a 'global' moment ${ }^{10}$.

These rebellions suggest the need to revise the limits of what are generally considered First World War histories, and also expand the histories of anticolonialism, decolonisation, and the emerging nationalisms in the twentieth century. To effectively do this, these rebellions needs to not only be discussed in relation to each other, but also in relation to their own antecedents. 


\section{The Saigon-Cholon Plot ${ }^{11}, 1913$}

The First World War touched more or less every corner of the globe in one way or another, including Southeast Asia. A 'state of siege' was declared in Indochina on 10 October 1914, two months after the war began in Europe, thus giving the colonial administration broad powers for repression and economic control, including opening up the courts martial for civil offenses ${ }^{12}$. In late 1914 and early 1915 colonial authorities launched a repression of suspected dissidents, arresting an as of yet unknown number of people whom the French considered to be potential agitators or revolutionaries ${ }^{13}$. In a rash act spurred by fear of food shortages Indochina was forbidden from selling trade goods, especially rice, to nations not allied with France. Given the huge importance of rice exports to the economy of Indochina, and Cochinchina especially, this came as a heavy blow to already-struggling farmers and agricultural workers ${ }^{14}$. Fortunately, the export ban lasted for only a matter of weeks. No recruitment was expected of Indochina until January 1916, and there was little to no worry of any serious insurrection. The Can Vuong (or 'Save the King') movement, the last major instance of primary anticolonial resistance, was an increasingly distant memory. Smaller scale rebels, like the 'pirate king' De Tham, had largely been mopped up by $1914^{15}$. Thus, Indochina entered the First World War relatively stable and secure, from a French perspective. The conditions of the war would change this, however, by introducing new pressures to Indochinese societies and exacerbating longstanding grievances. Indochina would suffer a series of rebellions from 1916 to 1918 . The largest of these was the 1916 rebellion in Cochinchina.

In order to truly understand the 1916 rebellion in and around Saigon we must first look back to 1913, and the radical movement of Phan Phat Sanh. Born in 1893 Phan Phat Sanh was the son of a Cholon police officer, who spent his youth as a boy servant to a French family ${ }^{16}$. In 1908 he fled to Siam, leaving his life of service behind him to pursue an independent career as a sorcerer and geomancer. He learned to read Chinese characters, apparently spent some time in religious seclusion as a monk, and eventually made a name for himself in Cambodia and Cochinchina as a respected healer and miracleworker adept in both the Buddhist arcane arts and 'the rough magic of modern Taoism' ${ }^{17}$. Before long Phan Phat Sanh fell in with a pair of revolutionaries (Nguyen Huu Tri, aka Hai-Tri, and Nguyen Van Hiep) who together sought to parlay Phan Phat Sanh's arcane prowess into real political power. After a period of building support and resources, during which Phan Phat

Sanh changed his name to Phan Xich Long, the movement culminated in a bold attempt to foment rebellion by attacking French power in Cochinchina at its heart. During the night of 23/24 March 1913 eight crudely made bombs were planted around critical sites in Saigon and Cholon. Five were planted in Saigon; one each outside the Governor General's mansion (near the stables), in the tirailleur Annamite ${ }^{18}$ camp outside of a barracks and near the French colonel's office, outside the Palais de Justice at the intersection of rue Lagrandière and rue Mac-Mahon, near the tram-tracks which led to Hoc-mon, and outside the Arsenal ${ }^{19}$. The remaining three were planted in Cholon in the marketplace, in front of the post office and outside of L'Inspection ${ }^{20}$.

Each bomb-planting team had been given potions of invisibility to mask their covert activity. Despite such careful precaution the bombs were discovered before they could be detonated. They were quickly linked to Phan Xich Long who had been arrested in Phan-Thiet the day before (22 March 1913) by gendarmes who stopped him in the street after seeing him walk past in sumptuous robes of white silk, bedecked in jewellery ${ }^{21}$. Such clothing would have been suspicious in any case, but were doubly so since his (falsified) identity papers listed his occupation as 'day labourer' under the alias 'Lac'. An investigation of his lodgings in the hôtellerie annamite turned up several other 'sumptuous' outfits, some of his 'crown jewels', a sword, an imperial seal proclaiming his ancestral ties to the Ming Dynasty, and also reams of magic spells and invocations designed for combat (rather than the normal healing or geomantic spells that one might expect to find on a wandering mystic $)^{22}$. 
The plot appeared to have been foiled when on 28 March 1913, four days after the bombs were discovered and removed, some 600 peasants wearing white robes and amulets of invincibility slowly wound their way through Saigon heading toward the heart of the city ${ }^{23}$. In theory, they were supposed to arrive in central Saigon just as the bombs were going off, at which time a deified Phan Xich Long would descend from the heavens and lead them in ousting the French ${ }^{24}$. French authorities soon learned about this strange gathering and quickly disbanded the peasants, arresting $111 \mathrm{of} \mathrm{them}^{25}$. Trial proceedings for months, and in some cases were extended into 1914 by lengthy, and often successful, appeals by the accused. The initial judgement came down on 13 November 1913.

Relative to the severity of punishment meted out against Indochinese rebels during the First World War the 60 sentences handed down in November 1913 were relatively lenient (at least within the brutal context of imperialism). Phan Phat Sanh (Phan Xich Long), Nguyen Van Ngo, Nguyen Van Hiep (Hiep), Nguyen Huu Tri (Hai-Tri), Truong Van Phuoc (Huong-Chu-Phuoc) and Nguyen Van Mang (Tu-Mang) were all given sentences of forced labour in perpetuity. The other 54 people sentenced on 13 November received various sentences.

\begin{tabular}{|l|l|}
\hline Sentence & Number of people \\
\hline 20 years forced labour & 6 \\
\hline 8 years forced labour & 8 \\
\hline 5 years forced labour & 1 \\
\hline 10 years detention & 1 \\
\hline 8 years detention & 1 \\
\hline 5 years detention & 9 \\
\hline 10 months in prison & 1 \\
\hline 8 months in prison & 24 \\
\hline 5 years interdiction de séjour ${ }^{26}$ & 1 \\
\hline Deported & 1 \\
\hline Absolved & 1 \\
\hline
\end{tabular}

Only one person listed, Nguyen Van Ky, was absolved ${ }^{27}$. Some estimates claim that over 100 people were sentenced to some form of punishment (usually small prison sentences) in the wake of the Saigon-Cholon affair ${ }^{28}$. For all intents and purposes the Saigon-Cholon affair seemed to be over.

\section{Unrest in Cochinchina, 1916}

Phan Xich Long was scheduled to be deported to Guyana to serve out his life of forced labour. These plans were disrupted by the outbreak of war in 1914, which made it difficult to arrange the necessary shipping to send him there ${ }^{29}$. This inconvenience did not seem to bother French administrators in the slightest. Phan's movement had been decried as the largest contest against French authority since the Can Vuong movement, even feared as a movement that was 'clearly insurrectional and, it must be said, nationalist', but it was now over and peace reigned in Cochinchina and Cambodia ${ }^{30}$. Reading reports from the Governor of Cochinchina, Jules Maurice Gourbeil, and the Governor General of Indochina (first Joost van Vollenhoven and later Ernest Roume) in the 19 months between the outbreak of war and the attack on Saigon Central Prison in February 1916 one is struck by the image of calm and loyalism that is projected. In Cambodia French reports claimed, probably correctly, that the mass of the population seemed completely uninterested in the war, and did not seem to see it as any sort of opportunity to oppose French rule ${ }^{31}$. While some revolutionaries like the famous Phan Boi Chau did see the war as an opportunity to strike, they were not in a position to do anything about it (Phan himself was imprisoned in China from 1914 to 1917, during which time he produced many of 
his most famous writings ${ }^{32}$. What unrest there was mostly concerned the normal friction between mountain and lowland peoples, pirates and buffalo thieves. Reporting in early 1915 Gourbeil noted that:

The mind-set of the Annamite population remains excellent; the indigenes, who have continued to follow news of the war with real interest, no doubt share our complete confidence in the triumph of our arms and their attitude suggests that...the current conflict could inspire them to better appreciate the benefits they already receive, and those that they still hope for in the future, by their closer and closer collaboration with France ${ }^{33}$.

Gourbeil's naïve, or more likely calculated, optimism glosses over a situation that was not entirely free from tension. Despite official declarations of loyalty from Cochinchinese delegations to the French colonial regime French officials decided it was best to take precautions against any potential unrest before it erupted. In line with metropolitan plans to round up dissidents, pacifists, and socialists on the outbreak of war if necessary, Gourbeil ordered the arrest of some known 'agitators' in late 1914/early 1915. These included 'Tu-Mat', one of the principle figures in the Saigon-Cholon Plot, who had managed to get an acquittal from the Saigon Court of Appeals in June/July 1913. He was arrested in early 1915 and eventually convicted of eight counts related to his seditious behaviour, with sentences varying from 5 to 30 years of imprisonment, in December that year ${ }^{34}$. French administrators and police could do this thanks to Indochina having declared a 'state of siege' (état de siège) on 10 October 1914, which granted broad powers to military officials in the colony, including the use of military courts for the general population ${ }^{35}$. This power would be rigorously used during the war, and set the stage for post-war abuses ${ }^{36}$.

Reports of relative tranquillity largely persist through 1915. Small matters still cropped up; some of them related to the war, others not. Economic issues loomed large, especially when the war began distorting the economy, driving up the cost of raw materials like timber, exploding the cost of European imports, and generating accusations of war-profiteering by Chinese merchants ${ }^{37}$. Similar economic disturbances occurred all over the world, and while they needed to be managed, they did not necessarily pose a critical problem ${ }^{38}$. There was even some evidence of direct support for the war including the vote to authorise a donation 10,000 piasters from Cochinchinese councils to support Indochinese volunteers serving abroad. It must be noted, however, that the notables and council members able to vote such sums had it in their own interests to express their loyalty to the French regime, thus helping ensure their privileged social position. Buried in the general optimism of reports, however, was evidence of discontent. This was most notable among those eligible for service overseas.

Following on from the official commencement of Indochinese mobilisation on 1 April 1915 the decree of 12 August 1915 made Indochinese recruits from 1913 and reservists from 1912 and 1911 eligible for service as labourers on the Western Front ${ }^{39}$. Even before the decree was announced fear of being sent overseas to fight in Europe had had a dramatic impact on recruitment. Confirmation of the recruits' worst fears made a bad situation much worse. Recruitment plummeted by nearly two-thirds (from 1330 in 1914 to just 460 in 1915), and desertion became rampant: some 30 per cent of the 2000 reservists called up were 'missing' by the end of the year ${ }^{40}$. Small bands of 'malefactors' (deserters and ex-prisoners) began to appear in some of the more wild, frontier provinces (especially Chau Doc), and a low-level malaise began to gently simmer in the provinces along the Cochinchinese-Cambodian border.

'Secret societies' began to operate more openly, and their ranks seemed to swell. One group at Gia Dinh was broken up and punished with minor fines/sentences as early as May 1915, but there were many more in operation ${ }^{41}$. These 'secret societies' were roundly criticised, repressed and feared by French officials who felt that they were at the core of most anticolonial activity in Indochina ${ }^{42}$. In reality they were a diverse body of social, political, and sometimes criminal, organisations that played 
interesting and vital socio-economic roles in the lives of many Indochinese peasants and labourers ${ }^{43}$. They provided not only a sense of community for the growing number of impoverished farmers and landless labourers, but also represented a rejection and replacement of the elite Indochinese society that these individuals did not have access to ${ }^{44}$. Some groups, like the famed Heaven and Earth Society, were imported from China and represented an important socio-political framework for the region's substantialethnic Chinese population ${ }^{45}$. The number and membership of secret societies appeared to grow rapidly in the early 1900s, partially as a result of easier travel and communication along newly-built infrastructure organised by the French, but also due to the increased French social and economic repression of Indochinese life and commerce which compelled individuals to find an outlet for their grievances. Secret societies played a major role in the 1913 Saigon- Cholon Plot and would play an even larger role in the 1916 Saigon attack.

Very soon after the recruitment of new Indochinese troops explicitly for overseas service was announced on 12 December 1915 the simmering in border regions finally boiled over ${ }^{46}$. In January 1916 Governor Gourbeil began to get worrying reports of unrest throughout Cochinchina. Secret societies were operating in the open, and when interrogated many members stated that they were preparing to rile the population up for a revolution ${ }^{47}$. Some investigations even turned up bombs or bomb-making materials and paperwork indicating a series of vast, and well-organised revolutionary societies. The first serious outbreak of violence occurred in Bien Hoa (just north-east of Saigon) on 24 and 25 January, barely six weeks after recruitment had been announced in Indochina. The initial violence broke out at a recruitment rally organised by Cochinchinese elites (the chef du canton of Chanh-my-Trung and the notables of Tan Trach village). They had set up near Bien Hoa and began exhorting young men to volunteer. Their pleas must not have been very convincing as they were soon attacked and 'mistreated' by a gang of men some 150-200 strong armed with lances, machetes and even a few stolen rifles ${ }^{48}$. These men then proceeded to go on something of a minor rampage, looting communal houses in Tan Trach and dispersing the local population ${ }^{49}$. The situation may well have degenerated into a full-scale riot had not the local French administrator Paul-Louis-Marie (Paul) Damprun rushed some Indochinese militia to the scene and began arresting the 'mutineers' (most of whom fled into the forest).

The men arrested on the 24th had been taken to the prison at Bien Hoa to await indictment and eventual trial. By 17.00 on the 25th they had broken out. A group of 15 prisoners supposedly led by Le Van Sot, a prisoner with a record of rebellion and insubordination, managed to catch a guard unawares and jump him ${ }^{50}$. Damprun ran out of his administrative residence to the sight of this Indochinese guard laying on the ground and being beaten. As he began shouting and gesticulating to get the prisoners to leave the man alone Le Van Sot, armed with a two-metre-long fire pump lever, turned towards Damprun and began chasing him. Le Van Sot struck Damprun once on the shoulder as he turned and ran back towards the residence. Le Van Sot took another swing at him as he crossed the threshold of the residence, but slipped and fell, thus allowing Damprun to grab a hunting rifle, which compelled Le Van Sot to quickly retreat to his comrades ${ }^{51}$.

While this was happening the other prisoners had broken into the guardhouse, armed themselves with carbines and opened fire on Damprun's residence. The noise drew the attention of the deputy administrator Antoine Émile Louis Cuniac (son of the former mayor of Saigon, Eugène Cuniac) and the gendarmes who raced to the scene. A general fire-fight broke out between the Europeans and the escaped prisoners that lasted some 45 minutes $^{52}$. Eventually the prisoners fled into the woods, leaving two dead and a few wounded (including Le Van Sot). Subsequent pursuit netted six arrests for French police and gendarmes. Later that evening, around 23.00, a band of 50 men (some of them undoubtedly were escaped prisoners) raided the village of Tan-Uyen, just 15 kilometres from Bien Hoa. The roving gang was confronted by the local garde forestier M. Vinot ${ }^{53}$ and a Vietnamese associate. Two shots rang out in quick succession, one of them killing the Vietnamese man and the other grazing Vinot's $\mathrm{arm}^{54}$. After this brief altercation the gang quickly dispersed back into the forest, probably fearing reprisal. Gourbeil responded by dispatching eight gendarmes and some auxiliaries to Bien Hoa by 
automobile the next day (26 January). By this point most of the former prisoners, deserters and 'vagabonds' (people who had left their homes and wandered the countryside to avoid de facto conscription) had already disappeared. Those few that were captured were reintegrated into the prison system $^{55}$.

Smaller-scale versions of this sort of unrest were shockingly commonplace across Cochinchina in January and February 1916. Large gangs of armed and often tattooed men, deserters, fugitives, revolutionaries, religious zealots and simple bandits roamed the country-side pillaging, ransoming, and generally harassing the populace ${ }^{56}$. It was a potent mixture of individuals that had analogues in previous periods of unrest, like the Tay Son $^{57}$. Gangs were seen in Ben Tre, Thu Dau Mot, Cap Saint-Jacques, Hoc Mon, Da-Phuoc, My Tho, Chau Doc, and Tay Ninh. In the end 13 out of the 20 regions in Cochinchina reported gangs of anywhere from 5-6 to over 300 individuals instigating violence, stealing and openly parading the presence of their anti-French revolutionary groups ${ }^{58}$. The appearance of so many rebel bands across such a broad geography at the same time as men across Indochina were attempting to avoid recruitment suggests a strong causal relationship between the two phenomena. All of this built up to a crescendo on the night of 14/15 February 1916.

\section{The Attack on Saigon Central Prison, 1916}

Beginning around the Tet Festival (3 February 1916) rumours began to circulate of secret gatherings and suspicious individuals slinking around the banlieues surrounding Saigon. The impoverished denizens of these areas began to suddenly leave, many of them desperately selling their wares at any price to get enough money to flee the city with their family. Early in the morning of 15 February, around 03.00, a group of boats disguised as banana merchant vessels floated up to the docks in central Saigon. Out of these boats poured somewhere between 100 and 300 rebels dressed in matching ceremonial clothing (black vests and white trousers), bearing amulets of invincibility, and carrying spears, machetes, cutlasses and a few revolvers ${ }^{59}$. The men disembarked and split up into groups, snaking through the streets from the docks to the Saigon Central Prison. As they advanced they began to shout 'Let's Free Big Brother!'; they had come to break Phan Xich Long out of Saigon Central Prison ${ }^{60}$.

Within minutes the groups had found themselves joined together again in front of the prison, with only a few minor mishaps along the way. One group took the opportunity they had to attack a random Frenchman they encountered with their cutlasses, wounding him badly but not killing him. Another group loudly protested before the stable doors of the palais du gouvernement before getting bored and re-joining their comrades in front of the prison. Reunited, the rebels attacked and killed an Indochinese guard, Gnanadicam, but found themselves locked out of the prison and unable to breach the sturdy iron doors ${ }^{61}$. On the other side of the prison walls the French and Indochinese guards were quickly issued rifles and cartridges. They opened fire, felling two of the 'rioters' in the first volley. The main French report describes the scene thusly:

We are obliged to believe that, frightened by the terrible effects of French bullets which had dropped several of them despite the virtue of their talismans [of invulnerability], they no longer dared to commit to a renewed attack [on the prison], and instead fled rapidly to Cholon, where they hoped to find a safe haven and perhaps some reinforcements ${ }^{62}$.

Despite the confusion French reports claimed that the rebels actually retreated in good order, marching under red banners proclaiming allegiance to Phan Xich Long. The rebels that remained (some undoubtedly fled at this point) began to march towards Cholon where they hoped to at least pillage the marketplace before daylight broke and they would have to disperse. French gendarmes 
pursued them in a commandeered tram, eventually catching up to them at the Station des Rizeries and disbanding the group with rifle-fire. In full flight the rebels fled west into a group of houses that had suffered a fire just days earlier, marking up their hands, faces and ceremonial silk trousers with thick soot. Cholon police, alerted to the disturbance, had mustered and began searching the area for dispersed rebels, easily identified in their soot-covered uniforms. Among them they found none other than Nguyen Huu Tri (Hai-Tri), one of the leaders of the gang who had managed to get himself acquitted for his role in the Saigon-Cholon Plot three years earlier, wounded and still carrying his bloodied lance ${ }^{63}$. By the end of the affair 8 men had been killed (including the guard Gnanadicam) and 65 had been arrested ${ }^{64}$.

The sheer scope of the rebellion was staggering, and sent shock waves that stretched all the way to Paris and the office of the Minister of Colonies, Gaston Doumergue. In addition to the attack in Saigon bands of rebels attacked the French administrative outpost in Ba Ria and the fortress at Cap Saint- Jacques that same night (14/15 February 1916) ${ }^{65}$. These rebel groups (numbering between 100 and 200) had coordinated their attacks with that on Saigon Central Prison, pointing to the existence of a vast, integrated rebel network ${ }^{66}$. The Ba Ria attack was led by none other than Nguyen Anh Hue, who had been tried, but ultimately acquitted, in the Saigon-Cholon Plot in 1913, further pointing to a long-standing organisation ${ }^{67}$. They carried the same weapons (largely out of necessity), bore the same amulets found on rebels who had taken part in the attack on Saigon Central Prison, and even marched under a banner proclaiming Phan Xich Long as their leader. The amulets and banners place the rebels (both in 1916 and 1913) in the long-running tradition of the Buu Son Ky Huong movement (Strange Fragrance from the Precious Mountain), a radical Buddhist revolutionary group that had operated in Cochinchina and Cambodia since the Lam San rebellion (1841-1842) and cholera outbreak of $1849^{68}$.

Cochinchina was a region rife with mystic revolutionaries in the nineteenth and early twentieth centuries, with major leaders appearing frequently ${ }^{69}$. What makes the 1916 Saigon attack stand out was the cooperation between many different groups across a broad geographic area, suggesting not just coordination, but also broadly-felt dissatisfaction with the realities of war-time Indochina. Some of the leaders of both the Saigon and Ba Ria attacks (namely 'Tu-Mat' in Saigon and Pham Van Khoe in Ba Ria) also had ties to the Heaven and Earth Society, a forerunner of the modern Triads ${ }^{70}$. The farrangingunderground connections of these secret societies may well have been truly vast. Unfortunately, documentary evidence for the organisation and motivations behind the rebellion are very thin. There is one single writing supposedly produced by the rebels appended to the French reports on the attack on Saigon Central Prison. The contents of the note, however, are disputed and not very helpful ${ }^{71}$.

Other, less proximate, Indochinese sources are also largely absent. Periodicals aimed at a Vietnamese readership were few in this period, and the newer publications that arose from 1916 onwards did so with support from French authorities, making them unhelpful in bringing out Vietnamese anticolonial voices in this time period ${ }^{72}$. Many studies on anticolonialism in the region rely, at least in part, on studies of documents from the Sûreté Général Indochinoise; however this body was not founded until 1917. Some fragments of the testimony from accused participants in the rebellion survive, however they only form parts of wider documents, rather than being preserved in their original form.

Testimony given by individuals was frequently contradictory. Initial interrogations often found suspects expressly saying that they served under the command of Phan Xich Long and sought to overthrow the French colonial regime, whereas subsequent interrogations often saw suspects deny having any part in the rebellion whatsoever ${ }^{73}$. French documents state that many of those indicted for participation in the attack on Saigon Central Prison claimed that their initial admissions were extorted out of them either through violence or threat of violence. While later French reports dismiss this possibility it seems more than likely that French authorities used physical violence against accused 
rebels in the immediate aftermath of their capture. The poor documentary record representing testimony from the accused was no doubt exacerbated by the extreme rapidity of the French response in the aftermath of the attack.

Unlike in 1913 the French repression was swift and brutal. No longer chained to the civilian legal system thanks to the declaration of a 'state of siege' French officials in Indochina unleashed a sustained repression of dissidents through the courts martial. Whereas many of the key players in the 1913 plot had managed to win acquittal through the courts of appeal sentences handed down in the courts martial were not so easily undone. 17 men were sentenced to death for their part in the attack at Ba Ria ( 8 of them in absentia); 38 were condemned to die for their part in the attack on Saigon Central Prison on 22 February, just one week after the attack. The sentences were carried out the next day in accordance with the decree of 10 October 1914 declaring a 'state of siege' in Indochina ${ }^{74}$. Further investigations and court proceedings led to 13 more individuals being sentenced to death on 14 March; they were executed the next day ${ }^{75}$. In the months that followed a vast repression of secret societies was carried out, leading to some 1660 detentions and 261 jail sentences ${ }^{76}$. For comparison, an estimated 46 revolutionaries were executed in India during the course of the entire war; 60 executions in Cochinchina alone within the space of three weeks amounted to a severe repression ${ }^{77}$. The reprisals were so severe that Cochinchina would not see any more secret society uprisings again until the 1920s, helping to pave the way for new nationalist and communist organisations to fill the void left by these societies both in peasant social life and in peasant political action ${ }^{78}$.

\section{The Underlying Causes of Unrest}

Determining the causes of a rebellion is never an easy task. Human beings are complex, and their societies even more so. In the end, we can only bring together a series of grievances and try to understand how they touched different people in different ways. This was fundamentally the challenge faced by a series of scholars of Southeast Asia in the aftermath of the American War in Vietnam. Samuel Popkin (The Rational Peasant: the Political Economy of Rural Society in Vietnam), Ngo Vinh Long (Before the Revolution: the Vietnamese Peasants Under the French) and James Scott (Moral Economy of the Peasant: Rebellion and Subsistence in Southeast Asia), among others, grappled with the difficulties of explaining or modelling the political behaviour of rural populations ('peasants'), whose voices and motivations are rarely well preserved ${ }^{79}$. Each author recounted, in some detail, the many injustices and injuries suffered by 'Vietnamese' people, but could not do much more than that to explain peasant politics, up to and including rebellion. Popkin, for his part, addressed the 1916 rebellion in Cochinchina specifically, simply noting that it was due to recruitment (this being in line with his principle idea that Vietnamese peasants revolted as an act of selfdefence ${ }^{80}$. Popkin's conclusion about the 1916 rebellion requires substantial nuance, which this article will now explore.

In the aftermath of the attack on Saigon Central Prison French authorities tried to determine amongst themselves why the uprising had erupted when it did. Most suspicion centred around the context of the First World War and the supposed influence of outside agitators: usually in the form of wellknown, exiled nationalist leaders. The trimestral report of the Governor of Cochinchina for the period of January to March 1916 (compiled in this instance by Louis Félix Marie Édouard Rivet, then assistant, and from 26 April acting, Governor of Cochinchina) suggested that, while the roots of the uprising were numerous, the primary causes were the prolongation of the war in Europe, which led some to believe that the French were weak and that now would be a good time to strike, and also the 'pretext' of recruitment for the war ${ }^{81}$. Above all else Rivet blames 'secret societies', which he felt had 
been insufficiently suppressed in preceding years (the maximum penalty for membership of a secret society had been 8 days in prison and a fine of 15 francs $)^{82}$. The bulk of the participants in the Saigon attack were disregarded out of hand as 'naïve peasants' who had been tricked by 'fake news' ( fausses nouvelles) into being the unwitting tools of ex-patriated nationalists and their agitators, or perhaps even the Germans ${ }^{83}$. In short, while Rivet (and other French officers and administrators) felt that the rebels may have had a range of grievances, the actions and effects of the French colonial regime on the lives of poor Indochinese workers and farmers were not principal among them ${ }^{84}$. Colonial authorities downplaying the deleterious effects of colonialism and economic exploitation were, of course, by no means unusual.

The French response in the immediate aftermath of the attack largely conforms to this belief. In the hopes of trying to at least put a stop to the immediate unrest Doumergue recommended on 24 February that recruitment in Cambodia and Cochinchina immediately cease, at least until the situation improved $^{85}$. The Governor General of Indochina, Ernest Roume, disagreed and allowed recruitment to continue, at least until the one partially-formed battalion of tirailleurs was filled. Roume felt that the recruitment had not been a problem in and of itself, but that it was merely taken as an excuse to rally support by the exiled Vietnamese Prince Cuong-De, Phan Boi Chau or perhaps even the exiled Cambodian Prince Yukanthor Monivong (supposedly supported by German money), who he felt were really behind the 1916 attacks (despite all evidence to the contrary) ${ }^{86}$. In response 1916 would see the creation of a Section des Affaires Politiques to more closely monitor political activity in Indochina, as well as the quiet codification and theoretical improvement of conditions for corvée labourers; a subtle suggestion that French administrators were at least somewhat willing to entertain the possibility that some of the rebels' grievances were justified ${ }^{87}$.

While Cuong-De, Phan Boi Chau and Prince Yukanthor did not have any part in the 1916 attacks it was nevertheless true that the rebels were undoubtedly motivated by a range of factors; not just recruitment and opportunism ${ }^{88}$. In order to assess the impact of the First World War on anticolonial activity it is necessary to weigh the circumstances of the war against pre-existing and parallel affronts and grievances borne by the Indochinese peasantry. De facto corvée labour, for example, was a profound source of substantial discontent and anger at the French regime (some suggest it was a major contributor to the 1913 Saigon-Cholon Plot) ${ }^{89}$. On 24 January 1916 some 5000 Cambodian peasants protested in Phnom Penh against forced labour on public works, especially road building/widening, thus expressing a sentiment that was no doubt broadly felt in Cochinchina ${ }^{90}$. The outpouring of anger in Cambodia over abuses that ultimately stemmed from the French colonial regime (even if interpreted and applied by Cambodian agents) grew to comprise at least 30,000 protesters from all over Cambodia, one of the largest protests of its kind in Cambodian history ${ }^{91}$. Interestingly, the protestors refused to engage with French officials, and appealed only and directly to the Cambodian monarchy for help. Given the similarities between conditions in Cambodia and Cochinchina, including the vast cross-border connections of the rebel movement of 1916, we have to assume similar levels of discontent over corvée labour. Having a monarch to appeal to no doubt made a peaceful protest more likely in Cambodia than in Cochinchina, where the only authority that could be appealed to was the French.

Corvée labour had technically been outlawed in 1887 but was still in widespread use by the French colonial government, and its Indochinese agents, to construct infrastructure like roads, irrigation, canals, railroads and dikes (to reclaim inundated land and make it suitable for the cultivation of rice). This work was grand in scale and enormously costly. The cost of widening and paving the $180 \mathrm{~km}-$ long road from Chau Doc to Soc Trang in 1915, for example, was estimated at 222,000 piasters $^{92}$. This infrastructure played a complex role in generating discontent and shaping the colonial landscape across European empires in this period. Most of the work on these systems relied on a mixture of 
unfree labour and poorly paid contract workers who often lived and worked in abysmally unhealthy conditions (including a lack of sufficient food) ${ }^{93}$.

New transport links were even associated with the widening influence of secret societies, and the spread of social ills including opium and human trafficking as organised crime took advantage of new means of transportation and communication ${ }^{94}$. Roads also allowed colonial tax collectors to more easily penetrate the countryside, bringing colonialism's most onerous of financial burdens to more and more people ${ }^{95}$. This was true across European empires ${ }^{96}$. Rebels in the Volta-Bani War in modern-day Mali and Burkina Faso made a powerful statement about the role European roads played by sowing millet over French roads as they had 'no use for them' ${ }^{97}$. In Indochina, dikes that kept fields from flooding were generally classed as 'public' work, and therefore subject to construction and maintenance via corvée labour, even though the profits made possible by these 'public' works were thoroughly private, and concentrated overwhelmingly in the hands of large European landowners. Forced labour to build vast infrastructure designed to better facilitate European economic exploitation of the region was an understandable cause of widespread discontent.

Indochina's social and economic changes ran deeper than the construction of transportation and communication infrastructure. During the late nineteenth and early twentieth centuries Cochinchina was reformed into a producer and exporter of raw materials (principally rice, but also exotic wood and other commodities). Both the exportation of rice and the importation of French manufactured goods expanded rapidly. From 1880 to 1937 rice exports from Saigon increased by 545 per cent (from 284,000 tonnes in 1880 to 1.548 million tonnes in 1937; up from just 57,000 tonnes in 1860), and the area cultivated grew by 421 per cent $^{98}$. In the interwar years Cochinchina became one of the largest rice exporters in the world. This increase in production and exportation came not from improved cultivation methods (a lack of capital in Indochina generally precluded such development), but from the sheer expansion of land being brought under cultivation. From 1900 to 1913 land used for growing rice grew from 1,174,000 hectares to 1,766,000 hectares ${ }^{99}$. By French estimates some 1.4 million hectares of farmland had been developed due to irrigation and other works by 1925; 89 per cent of which (1.25 million hectares) was in Cochinchina ${ }^{100}$.

Virtually all of the new land brought under cultivation was in the hands of large, absentee European landlords who had been granted land concessions. These were largely communal or uncultivated tracts of land taken by the colonial administration and then passed along to European investors at exceptionally low prices (less than 40 francs per hectare) ${ }^{101}$. This process was most acutely felt in Cochinchina where by 1915 fully 5 per cent of the total land area had been given away as concessions ${ }^{102}$. The expropriation of largely communal lands also undercut an important social safety net for struggling peasants who lacked the capital to purchase their own farmland, even if Cochinchina did not have the same tradition of set-aside communal lands for struggling and landless peasants that was common in Tonkin and Annam ${ }^{103}$. While setting aside land grants in the Mekong Delta had been common practice by the Nguyen Dynasty before the French conquest of Cochinchina in the 1860 s the size of these grants were much smaller. The sheer scale on which marginal alluvial, and later forested, lands were lost from 1860 to 1920 contributed significantly to the immiseration of peasants across Indochina ${ }^{104}$.

While more and more wealth, in the form of land, was being granted to Europeans in Indochina, a trade deficit saw money progressively leaving the region altogether. From 1890 to 1939 Indochina generally suffered an export-import ratio of 120-130 (meaning Indochina was importing goods worth, in total, 20-30 per cent more than they were exporting). This constituted a significant draining away of wealth, mostly to metropolitan France where most of the imports came from ${ }^{105}$. The system of granting large land concessions to European investors (consisting of expropriated communal, and at times private, land), compelling Indochina to import primarily from France and neighbouring 
Southeast Asian polities (protecting French exports from competition with their European counterparts), and restricting Indochina from selling its export rice freely on the global commodities market (an export economy that the French largely created) amounted to a heavy virtual tax on Indochinese people ${ }^{106}$. This system was made acutely painful in the early months of the First World War when export of rice from Indochina was barred to any nation not allied with France (although this ban was soon lifted $)^{107}$. Farmers who had grown dependent on the French orchestrated export economy faced economic ruin over a war they had nothing to do with.

The transition to an export economy centred on increasingly large plantations and commercial farming increased the need for migrant labourers. Most of the demand for migrant labour was met by the growing landless rural population, although some were imported from China and India. The loss of family subsistence farms was accelerated by simple population growth (there were fewer famines during the French colonial period than before, which consequently led to population growth), and French tax reforms which came to accept only cash payments, rather than payments in kind ${ }^{108}$. This forced many farmers on the margins to have to sell their plots and become tenant farmers or wage labourers. Those with enough capital after the sale to become tenants on what had formerly been their land paid substantial rents, sometimes as much as 1/5 of the land's purchase price each year, increasingly to European landlords. Many farmers in the early twentieth century, who had previously lived unmonetized lives, found themselves unable to afford the head tax of 0.4-2.5 piasters a year. According to Samuel Popkin some farmers even resorted to selling their children for cash to pay their taxes ${ }^{109}$.

The sheer financial burden of forced labour and substantially increased taxation (a 1000 per cent increase in the first 20 years of French rule in Indochina) to pay for European infrastructural projects (the single largest annual expenditure for most areas after administrative costs, representing roughly 18 per cent of local and federal budgets from 1900 to 1935, rising, on occasion, to as much as 40 per cent in 1909) and the maintenance of repressive armed forces represented a stark expropriation of wealth from some of the poorest individuals in the entire region ${ }^{110}$. To make matters worse, efforts to collect tax, including monopolies, were actually intensified in periods of economic difficulty as the colonial government desperately tried to maintain a steady revenue stream ${ }^{111}$. Peasants and the urban poor were hit doubly hard by any economic downturn.

In addition to head and land taxes the French had set up salt, opium and alcohol monopolies in an attempt to generate a reliable flow of revenue for the colonial regime ${ }^{112}$. While the monopolies began in nascent forms as early as 1897 , together they grew over the next twenty years into bureaucratic and repressive behemoths that reached deeper into Indochinese society than almost any other French institution. The monopoly system turned alcohol and opium into necessities (the local population was actually given consumption quotas), while making salt a luxury, despite its crucial importance to the fishing trade. Tonkin, Annam and Cochinchina would come to derive as much as 50-60 per cent of their income from these monopolies, thus making enforcement a top priority ${ }^{113}$. This created a system of repression, surveillance, and punitive fines which constituted a more substantial and onerous French intrusion into Indochinese life ${ }^{114}$. Fines for the consumption of 'black market' alcohol could be up to 500 francs (5000 piasters $)^{115}$. This would have been a fantastical sum for your average Indochinese worker who was generally paid from 0.30 to 0.70 piasters a day ${ }^{116}$. The monopolies further encouraged the sort of corporate cronyism that the colonial system thrived on, which circles back to the use of corvee labour and the exploitation of the colonised world for the profit of European enterprise ${ }^{117}$. Monopolies also encouraged and rewarded the development of a black market for the illicit trade of monopolised commodities. This, in turn, led to the expansion of criminal organisations to supply this trade, and to prey upon the increased number of desperate, migrant workers expropriated by French policies of land acquisition and heavy taxation. The spread of criminal organisations, and with them violence, banditry and human trafficking, was facilitated by 
French-built transport networks ${ }^{118}$. All of this combined to greatly increase the level of misery suffered by Indochinese peasants and labourers.

With all of these social, cultural and economic woes hitting Indochina at the same time (in addition to the above-mentioned changes the education system was also being radically reformed by the French in the early 1900s) we should not be too surprised that they experienced rebellious unrest ${ }^{119}$. Trying to determine which of these grievances were the most pressing, the most likely to lead to an outbreak of violence, can be difficult. This is doubly the case when we are dealing with movements composed primarily of illiterate peasants who do not often leave very good historical records ${ }^{120}$. There is evidence, however, to suggest that the conditions of the war (especially recruitment) were the primary drivers for the 1916 attacks; the final affront which demanded an organised response.

\section{Recruitment and the Effect of the War on Unrest}

If we consider Samuel Popkin's 1979 conceptualisation of 'the rational peasant' in Vietnam, which saw rebellion as a matter of self-defence, the grievances discussed above should have been more than enough to provoke anticolonial rebellions, even without the context of the First World War. The sharp shock of the war, however, and especially recruitment, cannot be underestimated. The threat of being coerced into service, or outright kidnapped, and shipped overseas with no guarantee that an individual would ever be able to return home, even if they survived the war, was both profound and, for most of the French empire, totally unprecedented. The arrival of a new and immediate threat to family integrity and bodily health was bound to engender a correspondingly acute response. A violent response was all but assured due to the substantial coercion that was involved in recruitment for service in Europe.

Writing in March 1916 Gaston Doumergue, Minister of Colonies in Paris, acknowledged that there had been certain 'abuses' in the recruitment procedures (namely coercion), blaming them on the conduct of Annamite subalterns ${ }^{121}$. The nature, indeed the existence, of these abuses remains a matter of some debate. The most recent and comprehensive work on the subject, Kimloan Vu-Hill's book Coolies into Rebels: Impact of World War I on French Indochina strongly takes the position that the Indochinese willingly volunteered for service in Europe, drawn by the 'wages, bonuses, pensions and other entitlements' promised ${ }^{122}$. Not only did the economic desperation of Indochinese peasants make volunteering a good option in Vu-Hill's analysis, but the very existence of wages, signing bonuses and other entitlements was 'inconsistent with them having been conscripted' ${ }^{123}$. Vu-Hill, however, fails to question the colonial system that saw so many Indochinese fall to a state of economic desperation. Vu-Hill also brushes aside the debates within French government and military circles over the issue of true conscription and the obligation it would put on metropolitan France to extend citizenship to colonial subjects. Payment and a thin veneer of volunteerism was a way to access colonial manpower without having to make any implicit political concessions in return ${ }^{124}$.

The argument that Indochinese recruits signed up willingly is seemingly rebutted later in Vu-Hill's own book which recounts how 'village notables in [some] provinces arrested and even chained peasants together, forcing them to sign [recruitment] contracts ${ }^{125}$. In the worst provinces listed, like Tay Ninh, 83 per cent of recruits had been kidnapped and forced to sign up, by Vu-Hill's own account. This does not seem to include individuals who were coerced, threatened or pressured in other ways, which means that at some times, in some provinces, the number of true volunteers who signed up without being subjected to any coercion (except perhaps basic economic pressure) may have been vanishingly small. In other colonies, like French West Africa, French assessments of their own recruitment efforts suggested that perhaps as little as 13 per cent of recruits had been true volunteers ${ }^{126}$. There was an understanding by certain colonial officials from across the empire that 
very few true volunteers were to be found among colonial recruits. The sheer number of desertions in 1915 and 1916 bear testament to the deep disgust that Indochinese men felt at the prospect of being sent overseas (crudely summed up as a lack of 'patriotic élan' by the French Minister of War, Joseph Gallieni) ${ }^{127}$.

It is worth underscoring the fact that forced recruitment was commonplace across France's overseas empire. What was happening in Indochina was not unique, but part of an empire-wide pattern of coercion. In Senegal recruits were offered up by families under pressure from local chiefs and religious authorities, or simply captured by raiding parties and delivered to the French in chains ${ }^{128}$. The situation elsewhere in French West Africa (Afrique Occidentale Française, AOF) was much the same ${ }^{129}$. In some cases recruits were drummed up by threatening local leaders if they failed to come up with enough recruits. In others recruitment was actively incentivized by paying recruiters a set fee per 'recruit' mustered (effectively turning recruitment into a new slave trade). Throughout the French empire would-be 'recruits' could either accept their fate, they could flee, or they could fight back ${ }^{130}$. The eruption of anticolonial uprisings spurred by opposition to recruitment in the Mali, Burkina Faso, Dahomey and Algeria (among others) should give us some inkling of the severity of French measures, and the response they provoked ${ }^{131}$. The parallels to Popkin's 'rational peasant' are striking, and suggest a strong causal link between the war (especially recruitment) and the explosion of anticolonial rebellions across the French empire.

The apparent necessity for such brutal recruitment measures is not difficult to understand when one considers the sheer level of recruitment that was being aimed at. In January 1916 Maurice Gourbeil set out the broad parameters for recruitment in Cochinchina in a telegram to local administrators. He set forth a quota of 2000 tirailleurs (combat troops), 3500 stewards and medical workers, 3000 unskilled labourers, and 50 translators: a total of $8550 \mathrm{men}^{132}$. To this initial 8550 Gourbeil suggested recruiting an additional 15 per cent to make up for any losses due to medical discharge, thus raising the minimum target to 9832 recruits. This was a truly fantastic number when one recalls that Cochinchina had only managed to raise 460 recruits for home service in 1915 . To put this further into perspective: all of Indochina had 16 battalions (roughly 14,000 men) in $1914^{133}$. Expecting the Cochinchina alone to drum up 9832 new recruits in their first recruitment drive seems optimistic, even if Indochina ultimately did send 50,000 troops to serve in Europe (half the number originally sought) ${ }^{134}$.

All of this is not to say that every recruit was kidnapped or otherwise coerced into service. There are many examples of wealthier families sending their sons to fight for the French, undoubtedly in expectation of gaining or maintaining favour with the colonial regime (members of Cambodia's royal family took a substantial role in the war, for example, both serving and overseeing recruitment ${ }^{135}$. For recruits of more modest means some were undoubtedly happy to volunteer in exchange for reliable pay, and no small number were indeed excited at the prospect of overseas adventure. These feelings, motivations and expressions (themselves potentially fleeting, or at any rate subject to change) do not, however, mean that no one was coerced into service, or that no one was justifiably angry about the French recruitment programme. A policy does not need to be universally disliked to spark a rebellion. It only has to enflame enough people to plan and carry out the uprising. An uprising was made more feasible not just by the existence of a strong grievance and acute threat,

but also by the weakened French presence in Indochina (and throughout their overseas empire) during the First World War.

The belief that France was being severely weakened by the war was a common response to the reduced European presence in Asia and Africa during the war ${ }^{136}$. The reduction of French troops in Cochinchina from 3956 to 2387 between August 1914 and March 1916 combined with the simultaneous expansion of Indochinese tirailleurs from 2873 to 3257 in the same period seemed to 
bear out the belief in French weakness ${ }^{137}$. In Tonkin the trend was even clearer: the number of French troops fell from 5733 to 3886 whereas Indochinese troops increased from 8735 to 10,633 in this same period $^{138}$. In total the number of troops in Indochina quickly fell from 23,000 before the war to below 18,000 , three-fourths of whom were Indochinese, within months of the outbreak of war ${ }^{139}$. Substantial and wide-ranging pressures combined with a weakening of the French presence in Indochina created both the motivation and the opportunity for rebellion.

The outbreak of war did not just leech away French soldiers from Indochina, it also prevented Phan Xich Long from being exiled to French Guyana in 1914 (shipping capacity was limited and had to be closely managed $)^{140}$. Phan Xich Long's presence in Saigon Central Prison gave the rebels a figurehead around which to rally, and probably allowed Phan to remain in contact with his supporters; the central prisons were in the heart of the city and prisoners had relatively easy access to communication with the outside ${ }^{141}$. If the First World War had not occurred when it did there is no reason to believe that Phan Xich Long would not have been successfully exiled to French Guyana, and without the acute unrest that arose from French efforts to recruit Indochinese soldiers for the war in Europe revolutionaries would have found it difficult to muster so vast and bold an organisation as they had in 1916. It should be noted that in 1916 the attackers were mostly (perhaps entirely) male, being largely deserters and other refugees. In 1913, by contrast, the peasants that proceeded down into central Saigon in their ceremonial dress were men and women, sometimes whole families, from villages and regions that had not previously shown signs of widespread unrest ${ }^{142}$. Those who took part in the 1916 attack were those most likely to be directly affected by the French recruitment policies.

If the war was not the only cause of the widespread violence in 1916 neither could the violence have occurred without the war. This violence was not merely an Indochinese problem, but wracked French North, West and Equatorial Africa. The fact that 1916 was also the most aggressive year for French colonial recruitment until 1918 should not be ignored ${ }^{143}$. This violence must be viewed as a symptom of the wider conflict, and part of its legacy.

\section{Other Rebellions}

The attack on Saigon Central Prison, and the broader unrest in Cochinchina, was not the only incident of anticolonial rebellion in Indochina during the First World War. There were two other incidents worth briefly discussing for their relevance to the broader history of anticolonialism in the period, and for the part they play in the evolution of anticolonialism and nationalism in Vietnam. The first of these was the Duy Tan rebellion. Duy Tan, the boy-emperor of Vietnam since 1907, was only fifteen in 1916 when he found himself swept up in an abortive uprising against the French. One of his mandarins, Tran Cao Van (himself a geomancer, like Phan Xich Long), thought they might have a window of opportunity in May 1916 to launch an uprising in the capital of Hué ${ }^{144}$. He was aware of the gross dissatisfaction of the men recruited for military service in Europe and sought to tap into their discontent to provide troops for a monarchist uprising ${ }^{145}$. His plan was to sneak Duy Tan out of the palace, get him out into the mountains, and then rally discontented runaways and deserters to their cause. During their preparations the French resident managed to catch wind of the plot and confined all local Indochinese soldiers to their barracks, thus effectively bottling up potential support for the uprising. Unaware of this, Tran Cao Van and Duy Tan made their attempt on the night of 2/3 May and were caught very shortly after ${ }^{146}$. Duy Tan was exiled to Réunion; six of his mandarin co-conspirators, including Tran Cao Van, were executed while others were imprisoned ${ }^{147}$.

While the extremely short-lived nature of the attempted rebellion may make Duy Tan's rebellion seem unimportant, the fact that the plan fundamentally rested on the well-known discontent over 
French recruitment for service overseas bears witness to the widespread reaction many had to recruitment in the First World War, and its power to spur anticolonial movements. Duy Tan's rebellion is also interesting as the last monarchist uprising in Vietnamese history. A year later, an early nationalist uprising in Tonkin, in which some members had already been convicted of resistance against the French over the issue of recruitment, would chart the path forward for Vietnamese anticolonialism.

The uprising at Thai-Nguyen Penitentiary in 1917 was unlike previous uprisings. It was neither religious nor class-based in its foundation. It consisted of people from all over Indochina and from all different walks of life: from simple brigands, to intellectuals, peasants, disillusioned soldiers, and seasoned guerrilla fighters; all of whom were imprisoned together at the Thai-Nguyen Penitentiary ${ }^{148}$. The specific details of the uprising have already been exhaustively covered by Peter Zinoman, both in his book The Colonial Bastille: A History of Imprisonment in Vietnam, 1862-1940 and also in a separate article; we need only very briefly recount the rebellion's key features here.

The rebellion erupted at Thai-Nguyen during the night of 30/31 August 1917 initially due to the harsh abuses of the French résident, Darles (under whose watch some 670 prisoners had died in the first 8 months of 1917), although wider concerns and anticolonial sentiment fed into the process ${ }^{149}$. In addition to the diverse status, experience and background of the rebels in Thai-Nguyen the rebellion is notable for its nationalist rhetoric and symbolism. A Vietnamese national flag was displayed in the penitentiary during the course of the first night (alongside a few severed heads). The flag itself was not just a nationalist symbol, but had elements of Pan-Asianism. The yellow of the five stars (one for each region of Indochina) was meant to represent all Asians, and the red field represented Vietnam.

The rebels issued a decree on 31 August 1917, no doubt heavily influenced by the intellectual leader of the uprising Luong Ngoc Quyen, a revolutionary whose career dated back to the early days of the Dong-Du movement in $1905^{150}$. It decried the many injustices Indochina had faced (including the recruitment of troops for service in Europe), and announced

The five-star flag has been raised; we have proclaimed independence. We are all brothers in the countries of Annam, intelligent men to whom education has been able to suggest some useful measures. Men of good health, aid us with your arms. Allow us to mobilize you, and you may join us to destroy our enemies ${ }^{151}$.

Further decrees from the 'Grand Chief of the liberating army of Thai-Nguyen province' lament the state of 'our country, Nam-Viet' and lay out the many complaints the rebels have against the 'French pirates' who have humiliated and pillaged their ancestral homelands, including proud (if often factually inaccurate) references to previous rebellions, including those of Phan Xich Long ${ }^{152}$. The implication is clear: the rebellion at Thai-Nguyen was presented as part of an ongoing struggle for national independence, even if the previous uprisings discussed were never overtly nationalist. ThaiNguyen was an uprising not for Tonkin, but for Vietnam.

Ultimately, the general insurrection was not to be. Rather than launch a guerrilla war the rebels chose to dig trenches and try to defend the town, unwittingly inviting the French to fight on terms that well suited an army that had spent three years fighting on the Western Front. The rebellion was irrevocably broken by French artillery fire within a matter of days (4 September 1917) ${ }^{153}$. The survivors scattered, and fled into the forest from which resistance was maintained until March 1918. Despite its 'failure' however, the Thai-Nguyen Rebellion was an important moment in the history of Vietnamese nationalism, and a fitting capstone to the anticolonial uprisings in Indochina during the First World War. The fact that similar nationalistic rhetoric was repeated at another, smaller uprising in Tonkin in November 1918, just after the signing of the armistice, should tell us that the early nationalism of 
Thai-Nguyen was not a flash in the pan, but was rather indicative of its time and place in history ${ }^{154}$. It was a sentiment that existed well beyond the penitentiary's walls.

In each of the rebellions discussed the First World War plays a greater or lesser part, offering both the opportunity and the impetus for bold anticolonial insurrections. Rather than a mere backdrop the war played an integral role in these rebellions, which in turn played critical roles in the longue duree struggle for independence across much of Africa and Asia. This should not be surprising.

The conduct and aftermath of the First World War is already credited with paving the way for social, cultural and political trends around the world that reverberated throughout the rest of the twentieth century, and in some cases beyond. Anticolonialism and the beginnings of later nationalism should be recognised as part of the wave of change that the First World War engendered or instigated. While the anticolonial uprisings in Indochina were not caused solely by the war, they were in many ways predicated on realities that the war made manifest; especially the prospect of being coerced into dangerous military service overseas. This was true throughout the French overseas empire, with analogous events occurring in parts of the Ottoman, British and Russian empires in Africa and Asia. The vast geographic and contextual scope of these uprisings strongly suggests that they are part of a shared global anticolonial aspect of the First World War and part of the war's substantial legacy.

\section{Notes}

\footnotetext{
${ }^{1}$ Archives Nationales d'Outre-Mer (ANOM), INDO Fonds Ministériels, nouveau fonds, carton 8, dossier 28 (2), Troubles en Cochinchine, 1916; “Le Gouverneur Général de l’Indochine à Monsieur le Ministre des Colonies (Service de l'Indochine - 2ème Section)"; Hanoi, 7 Décembre 1916. This article is based on English and French-language sources, and is intended for a broad audience interested in colonialism and the First World War, rather than being aimed exclusively at Southeast Asia experts. As a result diacritics are not used and names (of people and places) are generally presented as they are in the source material.

${ }^{2}$ This article will principally refer to the countries today known as Laos, Cambodia and Vietnam as 'Indochina', and will generally refer to northern, central and southern Vietnam by their colonial names: Tonkin, Annam and Cochinchina. This is done in the full understanding of the colonial imposition of the name on the regions in question. The term 'Vietnam' will generally be avoided as it is largely anachronistic to the early twentieth century, although it is used occasionally to help orient contemporary readers.

${ }^{3}$ Ibid.

${ }^{4}$ At the time of writing the only work to directly compare these disparate experiences is Frémeaux, Les Colonies de la Grande Guerre.

${ }^{5}$ Frémeaux, Les Colonies dans la Grande Guerre, 251-61.

${ }^{6}$ Ibid., 7.

${ }^{7}$ For example, Strachan, The First World War in Africa.

${ }^{8}$ Sanborn, Imperial Apocalypse, 3.

${ }^{9}$ Manela, The Wilsonian Moment, ix.

${ }^{10}$ In addition to the works already discussed (namely Frémeaux and Sanborn) we must add Fogarty, Race and War in France; Correale, La Grande Guerre des Trafiquants; Royer et al., West African Challenge to Empire; and Berhe, Notabili libici e Funzionari italiani, to say nothing of the works of Marc Michel, Gilbert Meynier, Alice Conklin, and others.

${ }^{11}$ Saigon and Cholon being urban centres which together make up modern day Ho Chi Minh City.

${ }^{12}$ ANOM, INDO FM, nf, carton 8, dossier 28 (2); Rapport de Service de l'Indochine, 26 Avril 1916.

${ }^{13}$ ANOM, Gouverneur Général de l'Indochine (GGI), 20068-20095, "Rapport sur la situation politique de la Cochinchine pendant le Ier trimestre 1915".

${ }^{14}$ Murray, The Development of Capitalism in Colonial Indochina (1870-1940), 197.

15 ANOM, INDO, nf 49, dossier 597, "Note sur les opérations de police dans la région du Yênthé"; this report details a major blow to De Tham's network, not long before he was eventually betrayed and killed in 1913.

${ }^{16}$ ANOM, INDO FM, nf, carton 8, dossier 28 (1); “Le Gouverneur Général de l'Indochine à Monsieur le Ministre des Colonies (Service de L’Indochine - Ière Section) Paris” 25 Décembre 1913.
} 
${ }^{17}$ Ibid., "magie grossière du taoïsme moderne".

${ }^{18}$ Tirailleurs Annamites was the French designation for Indochinese recruited into French-led armed forces.

${ }^{19}$ ANOM, INDO FM, nf, carton 8, dossier 28 (1); “Affaire du complot de Saigon-Cholon. Acte d'Accusation”.

${ }^{20}$ ANOM, INDO FM, nf, carton 8, dossier 28 (1); "Le Gouverneur Général de l'Indochine à Monsieur le Ministre des Colonies (Service de L'Indochine - Ière Section) Paris" 25 Décembre 1913.

${ }^{21}$ ANOM, INDO FM, nf, carton 8, dossier 28 (1); “Affaire du complot de Saigon-Cholon. Acte d'Accusation".

${ }^{22}$ Ibid.

${ }^{23}$ Tai, Millenarianism and Peasant Politics in Vietnam, 69.

${ }^{24}$ ANOM, INDO FM, nf, carton 8, dossier 28 (2); “Attentat contre la Prison centrale de Saigon (15 Février 1916), 1er Conseil de Guerre Permanent de la Cochinchine, Audience du 21 Février 1916 \& 13 +14 Mars, Réquisitoire du Lieutenant Héon, Commissaire du Gouvernement (Saigon: Imprimerie Commerciale C. Ardin, 1916)".

${ }^{25}$ ANOM, INDO FM, nf, carton 8, dossier 28 (1); "Le Gouverneur Général de l'Indochine à Monsieur le Ministre des Colonies (Service de L'Indochine - Ière Section) Paris" 25 Décembre 1913.

${ }^{26}$ Not allowed to leave Cochinchina.

${ }^{27}$ ANOM, INDO FM, nf, carton 8, dossier 28 (1); "Résultat des affaires concernant les accusés reconnues coupables par la Cour Criminelle de Saïgon; Affaire dit le 'Complot de Saïgon-Cholon, audience de 13 Novembre 1913".

${ }^{28}$ Marr, Vietnamese Anticolonialism, 223 \& ANOM, INDO FM, nf, carton 8, dossier 28 (1); "Affaire dite le 'Complot de Saigon-Cholon', Cour Criminelle de Saigon du 5 au 13 Novembre 1913, Réquisitoire de M. le Procureur Général G. Michel"; In his statements the Prosecutor General himself refers to some 109 individuals, 30 of Chinese ethnicity, 15 who had a low level of literacy in quôc-ngu, and 64 who were completely illiterate. The surviving reports do not recount this many sentences, guilty or not guilty, being handed down.

${ }^{29}$ Tai, Millenarianism in Peasant Politics in Vietnam, 72.

${ }^{30}$ ANOM, INDO FM, nf, carton 8, dossier 28 (2); "Attentat contre la Prison centrale de Saigon (15 Février 1916), 1er Conseil de Guerre Permanent de la Cochinchine, Audience du 21 Février 1916 \& 13 +14 Mars, Réquisitoire du Lieutenant Héon, Commissaire du Gouvernement (Saigon: Imprimerie Commerciale C. Ardin, 1916)".

${ }^{31}$ ANOM, Gouverneur Général de l'Indochine, 20068-20095, "Rapport Politique (4ème Trimestre 1914)", Gouvernement Général de l'Indochine, Protectorat du Cambodge, Cabinet du Résident Supérieur.

${ }^{32}$ Phan, Overturned Chariot, 237.

${ }^{33}$ ANOM, Gouverneur Général de l'Indochine (GGI), 20068-20095, "Rapport sur la situation politique de la Cochinchine pendant le Ier trimestre 1915"; "L'état d'esprit de la population annamite demeure excellent; les indigènes, qui continuent à suivre avec le plus réel intérêt les nouvelles de la guerre, partagent à n'en pas douter, notre absolue confiance dans le triomphe de nos armes et leur attitude permet de penser...que le conflit actuel a pu leur inspirer leur ont fait mieux apprécier les bénéfices qu'ils one déjà retirés et qu'ils ont encore à attendre, dans l'avenir, d'une collaboration de plus en plus étroite avec la France."

${ }^{34}$ Ibid.

${ }^{35}$ ANOM, INDO FM, nf, carton 8, dossier 28 (2); Rapport de Service de l'Indochine, 26 Avril 1916.

${ }^{36}$ In particular, the creation of a special criminal court in 1919 which provided legal cover for continuing the brutal war-time repression in peace-time; ANOM, INDO FM, nf, carton 58, dossier 646; "Pétition présentée par les familles des 36 victimes du Tribunal provincial de Vinh (Annam) à MM. Les Président et Membres de la Chambre des Députés à Paris" 14 Novembre 1929.

${ }^{37}$ ANOM, INDO FM, nf, carton 8, dossier 28 (2), "Extrait du Rapport sur la situation politique de la Cochinchine pendant le 2ème trimestre 1915" \& Lessard, "Cet ignoble traffic," 171.

${ }^{38}$ Manela, The Wilsonian Moment, 82 \& Bandyopadhyay, From Plassey to Partition, 132; In India, for example, the import of textiles declined by more than half during the war; this at a time when India was heavily reliant on imported British textiles.

${ }^{39}$ ANOM, INDO FM, nf, carton 8, dossier 28 (2), "Extrait du Rapport sur la situation politique de la Cochinchine pendant le 2ème trimestre 1915" \& Frémeaux, Les Colonies dans la Grande Guerre, 46.

${ }^{40}$ ANOM, INDO FM, nf, carton 8, dossier 28 (2), "Extrait du Rapport sur la situation politique de la Cochinchine pendant le 2ème trimestre 1915".

${ }^{41}$ ANOM, INDO FM, nf, carton 8, dossier 28 (2); "Extrait du Rapport sur la situation politique de la Cochinchine pendant le 3ème trimestre 1915".

${ }^{42}$ ANOM INDO FM, nf, carton 18, dossier 119, "Rapport sur la situation politique de la Cochinchine pendant 1e trimestre 1916; Situation politique - état d'esprit de la population - faits intéressant l'ordre public" \& Hill, "Millenarian Machines in South Vietnam," 327.

${ }^{43}$ Smith, "The Development of Opposition in Southern Vietnam 1880-1940," 108-109.

${ }^{44}$ Woodside, Community and Revolution in Modern Vietnam, 35.

${ }^{45}$ Peycam, The Birth of Vietnamese Political Journalism, 28. 
${ }^{46}$ Fogarty, Race and War in France, 46.

${ }^{47}$ ANOM, INDO FM, nf, carton 8, dossier 28 (2); "Le Gouverneur de la Cochinchine, à Monsieur le Gouverneur Général de l'Indochine”; Saigon, 3 Mars 1916, No. 122.

${ }^{48}$ ANOM, INDO FM, nf, carton 8, dossier 28 (2); "Rapport sur l'affaire Le-Van-Sot et Consorts (Affaire de Bienhoa). Exécution des prescriptions de la lettre No 1036 du Général Commandant Supérieur”.

${ }^{49}$ Ibid.

${ }^{50}$ ANOM, INDO FM, nf, carton 8, dossier 28 (2); "Le Gouverneur de la Cochinchine, à Monsieur le

Gouverneur Général de l'Indochine”; Saigon, 3 Mars 1916, No. 122

${ }^{51}$ ANOM, INDO FM, nf, carton 8, dossier 28 (2); "Rapport sur l'affaire Le-Van-Sot et Consorts (Affaire de Bienhoa). Exécution des prescriptions de la lettre No 1036 du Général Commandant Supérieur".

${ }^{52}$ Ibid.

${ }^{53}$ Vinot was one of a number of forestry experts sent to Indochina to help classify and protect Indochina's forests, largely to try to improve their economic value to European exploitation. Some of M. Vinot's clippings of vascular plants found in Phuoc-hoa Forest are still archived in the Muséum National d'Histoire Naturelle in Paris. McElwee, Forests Are Gold, 38-47.

${ }^{54}$ ANOM, INDO FM, nf, carton 8, dossier 28 (2); Télégramme, 92, 19 février 1916, Hanoi à Paris.

${ }^{55}$ ANOM, INDO FM, nf, carton 8, dossier 28 (2); "Le Gouverneur de la Cochinchine, à Monsieur le Gouverneur Général de l'Indochine”; Saigon, 3 Mars 1916, No. 122.

${ }^{56}$ Ibid.

${ }^{57}$ Dutton, The Tay Son Uprising, 212-13.

${ }^{58}$ Tai, Millenarianism and Peasant Politics in Vietnam, 73.

${ }^{59}$ ANOM, INDO FM, nf, carton 8, dossier 28 (2); Attentat contre la Prison centrale de Saigon (15 Février 1916), 1er Conseil de Guerre Permanent de la Cochinchine, Audience du 21 Février 1916 \& $13+14$ Mars, Réquisitoire du Lieutenant Héon, Commissaire du Gouvernement (Saigon : Imprimerie Commerciale C. Ardin, 1916).

${ }^{60}$ Tai, Millenarianism and Peasant Politics in Vietnam, 73.

${ }^{61}$ ANOM, INDO FM, nf, carton 8, dossier 28 (2); Attentat contre la Prison centrale de Saigon (15 Février 1916), 1er Conseil de Guerre Permanent de la Cochinchine, Audience du 21 Février 1916 \& 13 +14 Mars, Réquisitoire du Lieutenant Héon, Commissaire du Gouvernement (Saigon : Imprimerie Commerciale C. Ardin, 1916).

${ }^{62}$ Ibid.; "Nous sommes obligés de croire que, épouvantés par les effets foudroyants des balles françaises qui avaient jeté bas plusieurs des leurs malgré la vertu de leur talisman, ils n'ont plus osé commettre de nouvel attentat et se sont dirigés rapidement sur Cholon, où ils pouvaient espérer trouver avant le jour un asile sûr et peut-être même de nouveaux renforts."

${ }^{63}$ Ibid.

${ }^{64}$ Tai, Millenarianism and Peasant Politics in Vietnam, 73.

${ }^{65}$ ANOM, INDO FM, nf, carton 8, dossier 28 (2); "Le Gouverneur Général de l'Indochine à Monsieur le Ministre des Colonies (Service de l'Indochine - 2ème Section)"; Hanoi, 7 Décembre 1916.

${ }^{66}$ ANOM, INDO FM, nf, carton 8, dossier 28 (2); "Rapport sur l'affaire des nommés Nguyen Anh Hue et Consorts, dite affaire de Baria"; 14 Nov 1916.

${ }^{67}$ Ibid.

${ }^{68}$ Tai, Millenarianism and Peasant Politics in Vietnam, 9.

${ }^{69}$ Smith, "The Development of Opposition in Southern Vietnam 1880-1940," 54-101.

${ }^{70}$ Ward and Stirling, The Triads: The Hung Society, 1.

${ }^{71}$ ANOM, INDO FM, nf, carton 8, dossier 28 (2), Untitled letter from Liang Qiqing to Shi, Luo, Lin and Huang, 10th day of 2nd month, unknown year; translated by Edwin Black, DPhil candidate at the University of Oxford and Dr Nguyen To Lan of the Institute of Han-Nom Studies, Hanoi, Vietnam. This note has been looked at by three scholars: the above-mentioned two, plus Dr Liam Kelley of the University of Hawai'i at Manoa. The general consensus is that the letter concerns the movement of bodies of troops in a coordinated attack against French 'bandits'. Unfortunately the broader context is unclear. Edwin Black's translation is as follows:

施罗林黄 :

列位大老爷电照敬启者, 弟现奉冯统帅宪差委带队前来。

左良督率各营队伍会同进剿苏街法教二匪。弟于二十日抵左变, 明日到来, 并

有统宪札委仁兄公事, 请列位会同相酌。一切机宜, 并有调处安置等事, 请

移驾面叙, 以谈旧交为荷。专此, 即请升安, 希惟爱照, 不既列位老夫文

安。愚弟梁其清颐二月十日 $[\ldots]$

10th day of 2nd month [...]. 
Dear Messrs Shi, Luo, Lin and Huang,

As stated in my telegram, I am now bringing the army according to the official orders of Commander Feng.

The respected Supervisor Zuo leads each battalion of soldiers to jointly handle the suppression of the two bandit groups, the French and the Church. On the 22nd I reached Zuo's carriage, tomorrow I'll arrive. In addition the Commander's letter orders you to attend to some business, please each of you handle this jointly, considering it together. In addition to these principal matters, arrange for the garrisoning of the soldiers etc.

Please travel to meet me face to face, where we can speak as old acquaintances as well. This is my main purpose, to pay you the greatest respect, to hope only for your affection, as well as to pay respects to all the other gentlemen.

Yours sincerely,

Liang Qiqing, (Courtesy name: Yi).

${ }^{72}$ Peycam, The Birth of Vietnamese Political Journalism, 62.

${ }^{73}$ ANOM, INDO FM, nf, carton 8, dossier 28 (2), "Rapport sur l'affaire des nommés Nguyen Anh Hu et Consorts, dite affaire de Baria"; 14 Nov 1916.

${ }^{74}$ ANOM, INDO FM, nf, carton 8, dossier 28 (2); Rapport de Service de l'Indochine, 26 Avril 1916.

${ }^{75}$ ANOM, INDO FM, nf, carton 8, dossier 28 (2); Télégramme, 133, 17 mars 1916, Hanoi à Paris.

${ }^{76}$ Tai, Millenarianism and Peasant Politics in Vietnam, 73.

${ }^{77}$ Manela, The Wilsonian Moment, 82.

${ }^{78}$ Tai, Millenarianism and Peasant Politics in Vietnam, 77.

${ }^{79}$ Long, Before the Revolution; Popkin, The Rational Peasant \& Scott, The Moral Economy of the Peasant.

${ }^{80}$ Popkin, The Rational Peasant, xvii.

${ }^{81}$ ANOM INDO FM, nf, carton 18, dossier 119, "Rapport sur la situation politique de la Cochinchine pendant

1e trimestre 1916; Situation politique - état d'esprit de la population - faits intéressant l'ordre public".

${ }^{82}$ Ibid.

${ }^{83}$ ANOM, INDO FM, nf, carton 8, dossier 28 (2); "Le Gouverneur de la Cochinchine, à Monsieur le Gouverneur Général de l'Indochine”; Saigon, 3 Mars 1916, No. 122.

${ }^{84}$ ANOM INDO FM, nf, carton 18, dossier 119, "Rapport sur la situation politique de la Cochinchine pendant 1e trimestre 1916; Situation politique - état d'esprit de la population - faits intéressant l'ordre public".

${ }^{85}$ ANOM, INDO FM, nf, carton 8, dossier 28 (2); Télégramme, 253, 24 février 1916, Paris à Hanoi.

${ }^{86}$ ANOM, INDO FM, nf, carton 8, dossier 28 (2); Télégramme, 108 bis, 3 mars 1916, Saigon à Paris.

${ }^{87}$ ANOM INDO FM, nf, carton 18, dossier 119, "Rapport sur la situation politique de la Cochinchine pendant 1e trimestre 1916; Situation politique - état d'esprit de la population - faits intéressant l'ordre public" \& Murray, The Development of Capitalism in Colonial Indochina (1870-1940), 87.

${ }^{88}$ Frémeaux, Les Colonies dans la Grande Guerre, 265.

${ }^{89}$ Tai, Millenarianism and Peasant Politics in Vietnam, 70; the following discussion of corvée labour principally refers to tax-based corvée, although there are instances simple impressment as well.

${ }^{90}$ ANOM, INDO FM, nf, carton 8, dossier 28 (3); Dépêche Télégraphique, Hanoï, 28 Janvier 1916, Colonies, Paris \& Frémeaux, Les Colonies dans la Grande Guerre, 261.

${ }^{91}$ Milton, "Peasant Politics in Cambodia: The 1916 Affair," 217.

${ }^{2}$ ANOM GGI, 20068-20095, "Extrait du Rapport du 22 Avril 1915 du Gouverneur de la Cochinchine sur la Situation Politique de la Cochinchine Pendant le 1er Trimestre 1915".

${ }^{93}$ Murray, The Development of Capitalism in Colonial Indochina (1870-1940), 87.

${ }^{94}$ Lessard, "Cet ignoble traffic," 4-6.

${ }^{95}$ Edwards, "The Tyranny of Proximity," 427.

${ }^{96}$ For example in Indonesia: Mražek, Engineers of Happy Land.

${ }^{97}$ Royer \& Saul, West African Challenge to Empire, 9.

${ }^{98}$ Murray, The Development of Capitalism in Colonial Indochina, 58 \& 179.

${ }^{99}$ Huff, "Monetization and Financial Development in Southeast Asia," 307.

${ }^{100}$ Booth, "Night Watchman, Extractive," 256.

${ }^{101}$ Murray, The Development of Capitalism in Colonial Indochina, 179 \& 191.

102 Ibid., 191.

${ }^{103}$ Kleinen, "The Tragedy of the Margins," 456 \& Vu-Hill, Coolies into Rebels, 22.

${ }^{104}$ Kleinen, "The Tragedy of the Margins," 459-64.

${ }^{105}$ Huff, "Monetization and Financial Development in Southeast Asia," 327.

${ }^{106}$ Murray, The Development of Capitalism in Colonial Indochina, 197.

${ }^{107}$ ANOM INDO FM, nf, carton 18, dossier 119, "Rapport sur la situation politique de la Cochinchine pendant 1e trimestre 1916; Situation politique - état d'esprit de la population - faits intéressant l'ordre public".

${ }^{108}$ Kleinen, "The Tragedy of the Margins," 457.

${ }^{109}$ Popkin, The Rational Peasant, 245-46. 
${ }^{110}$ Murray, The Development of Capitalism in Colonial Indochina, 70 \& 174 \& Booth, "Night Watchman, Extractive," 246.

${ }^{111}$ Scott, The Moral Economy of the Peasant, 10.

${ }^{112}$ Sasges, Imperial Intoxication, 2 \& Tai, Radicalism and the Origins of the Vietnamese Revolution, 116.

${ }^{113}$ Murray, The Development of Capitalism in Colonial Indochina, 81 \& Booth "Night Watchman, Extractive," 246

${ }^{114}$ Sasges, Imperial Intoxication, 3.

${ }^{115}$ Brocheux, "Moral Economy or Political Economy," 792-93.

${ }^{116}$ Milton, "Peasant Politics in Cambodia: The 1916 Affair," 24.

${ }^{117}$ Tai, Radicalism and the Origins of the Vietnamese Revolution, 116.

${ }^{118}$ Lessard, "Cet ignoble traffic," 4-6.

${ }^{119}$ Keith, Catholic Vietnam, 77.

${ }^{120}$ ANOM, INDO FM, nf, carton 8, dossier 28 (2); "Le Gouverneur de la Cochinchine, à Monsieur le

Gouverneur Général de l'Indochine"; Saigon, 3 Mars 1916, No. 122.

${ }^{121}$ ANOM, INDO FM, nf, carton 8, dossier 28 (2); Confidential Telegraph (\#363) from Minister of the Colonies

to Governor General of Indochina in Hanoi, 24 March 1916.

${ }^{122} \mathrm{Vu}$-Hill, Coolies into Rebels, 9-10.

${ }^{123}$ Ibid.

${ }^{124}$ Fogarty, Race and War in France, 235-37.

${ }^{125}$ Vu-Hill, Coolies into Rebels, 47; Vu-Hill seems to specifically reference labourers being sent to France, although would-be combat troops received similar treatment.

${ }^{126}$ Fogarty, Race and War in France, 29-30.

${ }^{127}$ Ibid., 47.

${ }^{128}$ Lunn, Memoires of the Maelstrom, 39.

${ }^{129}$ Royer and Saul, West African Challenge to Empire, 105-106.

${ }^{130}$ Fogarty, Race and War in France, 46.

${ }^{131}$ Frémeaux, Les Colonies dans la Grande Guerre, 251-61.

${ }^{132}$ ANOM, INDO FM, nf, carton 8, dossier 28 (2); Télégramme Officiel, Gouverneur Cochinchine à tous Administrateurs, Saigon, 17 Janvier 1916.

${ }^{133}$ Frémeaux, Les Colonies dans la Grande Guerre, 30-34.

${ }^{134}$ Fogarty, Race and War in France, 27 \& Michel, Les Africains et la Grande Guerre, 50.

${ }^{135}$ Edwards, "The Tyranny of Proximity," 433.

${ }^{136}$ For West African comparison see Royer and Saul, West African Challenge to Empire, 297.

${ }^{137}$ ANOM GGI 66182, "Etat récapitulatif - Effectif Arme - Tonkin - Cochinchine".

${ }^{138}$ Ibid.

${ }^{139}$ Frémeaux, Les Colonies dans la Grande Guerre, 258.

${ }^{140}$ Tai, Millenarianism and Peasant Politics in Vietnam, 72

${ }^{141}$ Zinoman, The Colonial Bastille, 54-55.

${ }^{142}$ ANOM, INDO FM, nf, carton 8, dossier 28 (1); "Le Gouverneur Général de l'Indochine à Monsieur le Ministre des Colonies (Service de L'Indochine - Ière Section) Paris” 25 Décembre 1913.

${ }^{143}$ Fogarty, Race and War in France, 27.

${ }^{144}$ Tai, Radicalism and the Origins of the Vietnamese Revolution, 31 \& Frémeaux, Les Colonies dans la Grande Guerre, 259.

${ }^{145}$ Marr, Vietnamese Anticolonialism, 232.

${ }^{146}$ Ibid.

${ }^{147}$ Tran, A Vietnamese Royal Exile in Japan, 97.

${ }^{148}$ Zinoman, "Colonial Prisons and Anti-Colonial Resistance in French Indochina," 57.

${ }^{149}$ Frémeaux, Les Colonies dans la Grande Guerre, 260 \& Tai, Radicalism and the Origins of the Vietnamese Revolution, 31.

${ }^{150}$ Sinh, Phan Boi Chau and the Dong-Du Movement, 52-56 \& Phan, Overturned Chariot, 97; At the time Luong Ngoc Quyen was called Luong Lap Nham.

${ }^{151}$ Zinoman, "Colonial Prisons and Anti-Colonial Resistance in French Indochina," 65.

${ }_{152}$ ANOM, INDO FM, nf, carton 58, dossier 646; Annexe No 4 à la lettre No du Gouverneur Général de l'Indochine à Monsieur le Ministre des Colonies; Le 15 du 7e mois de la Ière année de DAI-HUNG-DE-QUOC; In this annex to a wider report are several translated proclamations issued by the rebels at Thai-Nguyen.

${ }^{153}$ Zinoman, The Colonial Bastille, 166.

${ }^{154}$ Frémeaux, Les Colonies dans la Grande Guerre, 260. 


\section{References}

Bandyopadhyay, Sekhar. From Plassey to Partition: A History of Modern India. New Delhi: Orient Longman, 2004.

Berhe, Simona. Notabili libici e Funzionari italiani: l'amministrazione coloniale in Tripolitania (1912-1919).

Soveria Mannelli: Rubbettino Editore, 2015.

Booth, Anne. "Night Watchman, Extractive, or Developmental States? Some Evidence from

Late Colonial South-East Asia." The Economic History Review, New Series 60, no. 2 (2007): 241-266.

Brocheux, Pierre. "Moral Economy or Political Economy, The Peasants are Always Rational." The Journal of Asian Studies 42, no. 4 (1983): 791-803.

Correale, Francisco. La Grande Guerre des Trafiquants: le front colonial de l'Occident maghrébin. Paris: Editions L'Harmattan, 2014.

Dutton, George. The Tay Son Uprising: Society and Rebellion in Eighteenth-Century Vietnam. Honolulu: University of Hawai'i Press, 2006.

Edwards, Penny. "The Tyranny of Proximity: Power and Mobility in Colonial Cambodia, 1863-1954.” Journal of Southeast Asian Studies 37, no. 3 (2006): 421-443.

Fogarty, Richard S. Race and War in France: Colonial Subjects in the French Army, 1914-1918. Baltimore, MD: John Hopkins University Press, 2008.

Frémeaux, Jacques. Les Colonies de la Grande Guerre: Combats et Épreuves des Peuples d'Outre-Mer. Soteca: 14-18 Éditions, 2006.

Hill, Frances R. "Millenarian Machines in South Vietnam." Comparative Studies in Society and History 13, no. 3 (1971): 325-350.

Huff, W. G. "Monetization and Financial Development in Southeast Asia Before the Second World War." The Economic History Review 56, no. 2 (2003): 300-345.

Keith, Charles. Catholic Vietnam: A Church from Empire to Nation. Berkeley, Los Angeles, London: University of California Press, 2012.

Kleinen, John. "The Tragedy of the Margins: Land Rights and Marginal Lands in Vietnam (c. 1800-1945)." Journal of the Economic and Social History of the Orient 54, no. 4, Long- Term Changes in Land-Tenure Arrangements in Pre-Modern and Early-Modern Southeast Asia (2011): 455-477.

Lessard, Micheline. “'Cet Ignoble Traffic': The Kidnapping and Sale of Vietnamese Women and Children in French Colonial Indochina, 1873-1935.” French Colonial History 10 (2009): 1-34.

Long, Ngo Vinh. Before the Revolution: The Vietnamese Peasants under the French. New York: Columbia University Press, 1973.

Lunn, Joe. Memoires of the Maelstrom: A Senegalese Oral History of the First World War. Oxford: James Currey Ltd, 1999.

Manela, Erez. The Wilsonian Moment: Self-Determination and the International Origins of Anticolonial Nationalism. Oxford: Oxford University Press, 2007.

Marr, David G. Vietnamese Anticolonialism. Berkeley, Los Angeles and London: University of California Press, 1971.

Michel, Marc. Les Africains et la Grande Guerre: l'appel à l'Afrique (1914-1918). Paris: Édition Karthala, 2014.

Milton, Osborne. "Peasant Politics in Cambodia: The 1916 Affair.” Modern Asian Studies 12, no. 2 (1978): 217-243.

McElwee, Pamela D. Forests Are Gold: Trees, People, and Environmental Rule in Vietnam. Seattle: University of Washington Press, 2016.

Mražek, Rudolf. Engineers of Happy Land: Technology and Nationalism in a Colony. Princeton: Princeton University Press, 2002.

Murray, Martin J. The Development of Capitalism in Colonial Indochina (1870-1940). Berkeley, Los Angeles, London: University of California Press, 1980.

Peycam, Philippe. The Birth of Vietnamese Political Journalism: Saigon, 1916-1930. New York: Columbia University Press, 2012.

Phan, Boi Chau. Overturned Chariot: The Autobiography of Phan-Boi-Chau. Honolulu: University of Hawai'i Press, 1999.

Popkin, Samuel L. The Rational Peasant: The Political Economy of Rural Society in Vietnam. Berkeley and Los Angeles: University of California Press, 1979.

Royer, Patrick, and Mahir Saul. West African Challenge to Empire: Culture and History in the Volta-Bani Anticolonial War. Oxford: James Currey, 2001.

Sanborn, Joshua A. Imperial Apocalypse: The Great War and the Destruction of the Russian Empire. Oxford: Oxford University Press, 2014. 
Sasges, Gerard. Imperial Intoxication: Alcohol and the Making of Colonial Indochina. Honolulu: University of Hawai'i Press, 2017.

Scott, James C. The Moral Economy of the Peasant: Rebellion and Subsistence in Southeast Asia. New Haven and London: Yale University Press, 1976.

Sinh, Vinh. Phan Boi Chau and the Dong-Du Movement. New Haven, CT: Yale University Press, 1988.

Smith, R. B. "The Development of Opposition to French Rule in Southern Vietnam 1880-1940." Past and Present 54 (1972): 94-129.

Strachan, Hew. The First World War in Africa. Oxford: Oxford University Press, 2004.

Tai, Hue-Tam Ho. Millenarianism and Peasant Politics in Vietnam. London: Harvard University Press, 1983.

Tai, Hue-Tam Ho. Radicalism and the Origins of the Vietnamese Revolution. Cambridge, MA \& London, England: Harvard University Press, 1992.

Tran, My-Van. A Vietnamese Royal Exile in Japan: Prince Cuong-De (1882-1951). Abingdon: Routledge, 2005 .

Vu-Hill, Kimloan. Coolies into Rebels: Impact of World War I on French Indochina. Paris: Les Indes Savantes, 2011.

Ward, J. M. S., and W. G. Stirling. The Triads: The Hung Society or the Society of Heaven and Earth. London: Kegan Paul, 2006.

Woodside, Alexander B. Community and Revolution in Modern Vietnam. Boston: Houghton Mifflin Company, 1976.

Zinoman, Peter. "Colonial Prisons and Anti-Colonial Resistance in French Indochina: The Thai Nguyen Rebellion, 1917." Modern Asian Studies 34, no. 1 (2000): 57-98.

Zinoman, Peter. The Colonial Bastille: A History of Imprisonment in Vietnam, 1862-1940. London: University of California Press, 2001. 